\title{
СЕМАНТИЧЕСКАЯ СТРУКТУРА ГЛАГОЛА ОМНАТІ 'СИДЕТЬ’ В ХАНТЫЙСКОМ ЯЗЫКЕ (НА МАТЕРИАЛЕ ШУРЫШКАРСКОГО ДИАЛЕКТА)
}

\section{Нахрачева Г.Л.}

Цель. Статья посвящена выявлению и описанию лексико-семантических вариантов хантыйского глагола отәstĭ 'cидеть'. Поскольку семантика глагола неразрывно связана с его сочетаемостью, исследование системы многозначного глагола опирается на его реализацию в контексте. Значения многозначного глагола отәstй вblводятся из его лексического окружения, его сочетания с другими лексемами. Именно сочетаемость выступает как условие реализации того или иного значения.

Метод или методология проведения работы. Основным материалом для исследования послужила картотека, составленная автором путем сплошной выборки примеров из фольклорных, художественных произведений, а также массив примеров из текстов, опубликованных в хантыйской газете «Лухавт». Кроме всего использовались данные словарей, полевые записи автора. При сборе языкового материала в местах проживания ханты использовались традиционные приемы: опрос, наблюдение, фиксация устной речи при помощи технических средств.

Исходя из общей изели исследования, в работе использовались следуюшие методы: метод контекстного (дистрибутивного) анализа, позволяющий выявить различные значения и оттенки значений исследуемого глагола, и экспериментальный анализ, связанный с работой информантов, при помощчи которых проводилось уточнение значений глагола.

Результаты. Как показывает наше исследование, глагол отәstй представлен в современном хантыйском языке 10 лексическими зна- 
чениями, которые детализируют семантический признак «опора на поверхность».

Область применения результатов. Материалы и выводы исследования могут быть использованы при составлении словарей хантыйского языка, при чтении вузовских курсов и написании учебных пособий по курсам грамматики и лексикологии хантыйского языка.

Ключевые слова: хантыйский язык; глагол; семантика; сочетаемость; семантическая структура слова; лексико-семантический вариант.

\section{SEMANTIC STRUCTURE OF THE VERB OMHSTĬ 'TO SIT' IN THE KHANTY LANGUAGE (AS BASED ON THE SHURYSHKAR DIALECT)}

\section{Nakhracheva G.L.}

Purpose. The article is devoted to identification and description of the lexical-semantic variants of the Khanty verb omastī 'to sit'. Due to the fact that the semantics of the verb is inseparably connected with its co-occurrence, studying the system of the polysemantic verb is based on its realization in the context. Meanings of the polysemantic verb omast are derived from its lexical circle, as well as its combination with other words. Combinability with different words is a prerequisite to the realization of a certain meaning of the verb.

Methodology. The basic material of the study was a card catalogue compiled by the author through continuous sampling of examples from the folklore, artistic works and the materials from the texts published in the Khanty newspaper Lukhavt.

In addition, dictionaries data as well as the author's field materials were used. In the process of the language material collecting in the Khanty's places of residence, traditional techniques were used, such as survey, observation, fixation of oral speech with the help of technical means. 
Based on the overall goal of the research work the methods used were as fololows: the method of contextual (distributional) analysis, which reveals different meanings and shades of meaning of the examined verb, as well as the experimental analysis associated with the informants, used to clarify the meanings of the verb.

Results. It has been shown that the verb omastüis is presented in the modern Khanty language by 10 lexical meanings, detailing the semantic feature 'footing at the surface'.

The scope of the results of the study. Materials and conclusions of the study can be used in the preparation of the dictionaries of the Khanty language, with reading University courses and writing textbooks for courses of lexicology and grammar of the Khanty language.

Keywords: Khanty language; verb; semantics; co-occurrence; semantic structure of the word; lexical-semantic variant.

Целью данной статьи является анализ лексико-семантических вариантов многозначной лексемы oməsti “сидеть' в хантыйском языке. Наша задача - представить значения данного глагола как некоторую систему.

По своей семантике данный глагол oməstı̆ мы относим к глаголам статической пространственной локализации, к так называемым «позиционным глаголам». Это глаголы, включающие в свою семантику значение расположения субъекта либо объекта в пространстве. Глаголы, которые инкорпорируют этот семантический компонент, называются «позиционными» глаголами [4, с. 285]. Данный глагол уточняет позицию предмета своей собственной семантикой, детализируют своим значением семантический признак «опора на поверхность».

На материале казымского диалекта хантыйского языка ЛСГ глаголов пространственной локализации была частично описана в работах В.Н. Соловар [5, с. 36], А.Ю. Фильченко, О.С. Потаниной [7, с. 62-72], Е.В. Кашкина [2, с. 78-88], описание данных глаголов выполнено в словарях шурышкарского диалекта С.И. Вальгамовой, Н.Б. Кошкаревой, С.В. Ониной, А.А. Шияновой [1], Ф.М. Лельховой [3] и казымского диалекта В.Н. Соловар [6].

Мы попытаемся выявить все имеющиеся лексические значения исследуемого глагола. 
Основное значение лексемы oməstĭ 'сидеть, садиться - принять сидячее положение' (ЛСВ $)$ : Ma motxătt wuš ettı̆ tăta oməstəm 'Я со вчерашнего дня тут сижу'; Ješauł kuśajyałał uxła oməsłə引ən 'Скоро хозяева в сани сядут'; At kŭtəp unť̆ pŏtartman omassat 'До пол ночи сидели и разговаривали'; Ow jetpijən amp oməsat 'Перед дверями сидит собака'; Jŏxətmewn, mŏxat păsan surn oməstat ' 'Когда мы пришли, люди за столом сидят'; Pirəś imi urxot kŭtepn oməsəł, rat šŏmaja 'Сидит старуха посреди чума, напротив костра'; Imen jotn oməsat 'Твоя жена дома сидит'; Łor

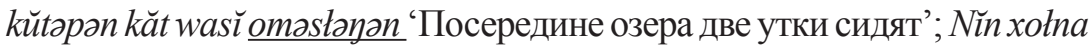
omastatĭ? 'Вы еще сидите?'; Nin it opsatǐ ‘Вы садитесь'. Из приведенных примеров видно, что субъектами являются человек и животные.

ЛСВ 'поставить - поместить что-либо в определенное место

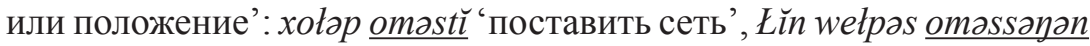
'Они поставили ловушку'; Wetra nŏremn omsst 'Ведро стоит на полке'; Śaj pŭten kur łoyła opsĭ 'Поставь чайник на печку’; Xołəp kurt łepən omassəw 'Сети недалеко от деревни поставили'; Tima iki

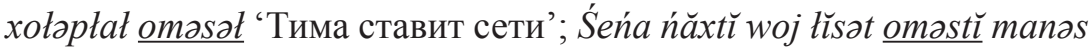
'Сеня пошел ставить сети на куропатку'.

ЛСВ ' 'посадить - придавать устойчивое положение, помещая близко к земле или другой прочной опоре': Maj ŭx omassam 'Я посадил дерево'; Aśemən xора oməssajum 'Отец=мой посадил меня в лодку'; Kartoška pakămn tŏrn oməssəw 'Посадили картошку и разные травы’;

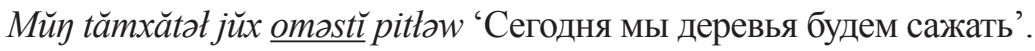

В значении 'построить' глагол oməstĭ сочетается с названиями различного рода построек, например, дом, лабаз и др. (ЛСВ $)$ : Aśem jałəp xot omsas 'Отец=мой построил (букв.: посадил) дом'; tüw jăjała xot omsastı̌ ńotas 'Он помог построить дом брату'; Un tăśkam xot omasłat 'Большой просторный дом строят'; Jăłəp łŏpas opsəm 'Новый лабаз построен'; Jajtam xot oməstat 'Братья=мои дом строят'.

$\pi \mathrm{B}_{5}$ 'замесить - приготовить, смешивая какое-нибудь сыпучее вещество с жидкостью и разминая для получения вязкой массы': sŭr oməsť̆ 'приготовить брагу'; Ma ńań šŭmoməsłəm 'Я тесто замешу (букв.: поставлю)'; Imətńań šŭ omsəs' Жена=его тесто замесила (букв.: поставила)'; Nań omastǐ mosət 'Тесто на хлеб надо замесить'. 
ЛСВ ${ }_{6}$ 'отелиться - родить телёнка (о корове, самке оленя, лося и некоторых других парнокопытных животных)': Ne ŭtem xănša sŭjəw oməsmat 'Важенка родила пёстрого оленёнка'; Misew towijən opsas 'Корова весной отелилась'; Sujəw oməstı̌ tit'śa jis 'Настал месяц отела (букв.: теленка садить)'.

ЛСВ 'сесть, опуститься за горизонт, зайти (о солнце)':Xătt opsas' 'Солнце село’.

ЛСВ ${ }_{8}$ 'стоять, располагаться, находиться (о постройках, поселении, транспортных средствах)': Katra xot xolna oməsat 'Старый дом еще стоит'; In kurtən kirpəś kur oməsat 'Сейчас в деревне кирпичная печь поставлена'; Păt săyxәmn Owkurt omasat 'На высоком холме расположен поселок Овгорт’; Muši woš As puyətn omasat ‘Село Мужи расположено на берегу Оби’; Jăฑxəm xopem tăta śi oməsət 'Лодка, на которой ездил, здесь вот стоит'; Namn kăt xop omasat 'На берегу две лодки стоят'; Xopew ŭtən omasat 'Лодка на берегу возле леса стоит '; Uxłat kŭrəy tŏpas itpijan oməsłat 'Нарты стоят под лабазом на ножках’ .

В значении 'расставить' (ЛСВ $)$ глагол отәsť̆ сочетается с превербом lakki: Utassat lakki oməsłałəm 'Стулья расставлю’.

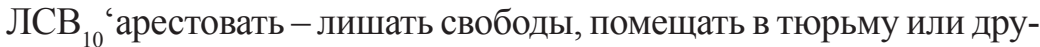
гое место заключения', это значение реализуется при сочетании дан-

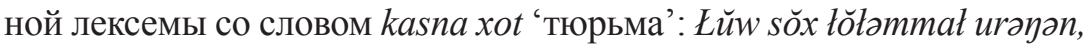
kasna xota oməssa 'за то, что он украл шкуру, его посадили в тюрьму'.

В значении 'поставить к костру' (ЛСВ 11 ) глагол oməstĭ сочетает-

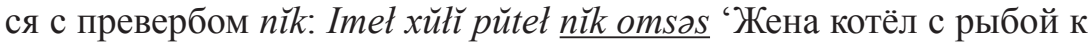
костру поставила'.

Итак, на примере глаголов omssť мы рассмотрели актуализацию значений данного многозначного глагола. Все ЛСВ объединяет признак «опора на поверхность», они мотивируются основным значением глагола, и смысловая структура этого глагола по принципу связей ЛСВ друг с другом относится к радиальному типу полисемии.

\section{Список литературы}

1. Вальгамова С.И. Диалектологический словарь хантыйского языка (шурышкарский и приуральский диалекты). Екатеринбург: Баско, 2011. 208 c. 
2. Кашкин Е.В. Семантика хантыйских позиционных предикатов// Проблемы лексико-семантической типологии: сборник научных трудов Третьей Международной научной конференции. 2016. С. 78-88.

3. Лельхова Ф.М. Словарь глаголов хантыйского языка (шурышкарский диалект). Ханты-Мансийск: Новости Югры, 2012. 207 с.

4. Рахилина Е.В. Когнитивный анализ предметных имен: семантика и сочетаемость. М.: Русские словари, 2000. 415 с.

5. Соловар В.Н. Парадигма простого предложения в хантыйском языке (на материале казымского диалекта). Новосибирск: Любава, 2009. $264 \mathrm{c}$.

6. Соловар В.Н. Хантыйско-русский словарь (казымский диалект). Тюмень: Формат, 2014. 386 с.

7. Фильченко А.Ю., Потанина О.С. Предикативная поссесивность в восточных диалектах хантыйского языка // Томский журнал лингвистических и антропологических исследований. 2016. № 4(14). С. $60-72$.

8. Шилова В.В. Пространственные модели элементарных простых предложений в ненецком языке. Новосибирск: Новосиб. гос. ун-т., 2003. Ч. 1. 106 с.

\section{References}

1. Valgamova S.I. Dialektologicheskiy slovar khantyyskogo yazyka (shuryshkarskiy i priuralskiy dialekty) [Dictionary of the dialects of the Khanty language (Shuryshkar and Uralic dialects)]. Ekaterinburg: izd-vo«Basko» Publ., 2011. 208 p.

2. Kashkin E.V. Semantika hantyjskih pozicionnyh predikatov [The semantics of positional predicates in the Khanty language]. Problemy leksiko-semanticheskoj tipologii: sbornik nauchnyh trudov Tret'ej Mezhdunarodnoj nauchnoj konferencii [Issues of lexical and semantic typology: collection of scientific proceedings of the $3^{\text {rd }}$ International scientific conference]. Voronezh, 2016, pp. 78-88.

3. Lelkhova F. M. Slovar' glagolov hantyjskogo yazyka (shuryshkarskij dialekt) [Dictionary of the verbs of the Khanty language (Shuryshkar dialekt)]. Khanty-Mansijsk: NovostiYugry Publ., 2012. 207 p. 
4. Rahilina E.V. Kognitivnyj analiz predmetnyh imen: semantika i sochetaemost' [Cognitive analysis of subject names: semantics and co-occurrence]. Moskow, Russkieslovari Publ., 2000. 415 p.

5. Solovar V.N. Khantyysko-russkiy slovar [The Khanty-Russian dictionary]. Saint-Petersburg: izd-vo «Mirall» Publ., 2006. 333 p.

6. Solovar V. N. Paradigma prostogo predlozheniya $v$ khantyyskom yazyke (na materiale kazymskogo dialekta) [Paradigm of a simple sentence in the Khanty language (on the material of the Kazym dialect)]. Novosibirsk: Lyubava Publ., 2009. 264 p.

7. Fil'chenkoA.Yu., Potanina O.S. Predikativnaya possesivnost' v vostochnyh dialektah hantyjskogo yazyka [Predicative possesively in the Eastern dialects of the Khanty language]. Tomskij zhurnal lingvisticheskih iantropologicheskih issledovanij [Tomsk journal of linguistics and anthropology], 2016, no. 4 (14), pp. 60-72.

8. Shilova V.V. Prostranstvennye modeli jelementarnyh prostyhpredlozhenij v neneckom jazyke [Spatial models of elementary simple sentences in Nenets language]. Novosibirsk: Novosib. gos. un-t. Publ., 2003, P. 1. 106 p.

\section{ДАННЫЕ ОБ АВТОРЕ}

Нахрачева Галина Леонидовна, ведущий научный сотрудник, кандидат филологических наук

БУ «Обско-угорский институт прикладных исследований и разработок»

ул. Мира 14A, г. Ханты-Мансийск, 628007, Российская Федерация

galina-nakhracheva@rambler.ru

\section{DATA ABOUT THE AUTHOR}

Nakhracheva Galina Leonidovna, Leading Researcher, Candidate of Philological Sciences

Ob-Ugric Institute of Applied Research and Development 14A, Mira Str., Khanty-Mansiysk, 628007, Russian Federation galina-nakhracheva@rambler.ru 